\title{
Record of glacier variations during the last glacial in the Turkestan range of the Pamir-Alay, Kyrgyz Republic
}

\author{
Chiyuki NARAMA, ${ }^{1}$ Mitsuru OKUNO ${ }^{2}$ \\ ${ }^{1}$ Department of Environmental Studies, Nagoya University, Nagoya 464-8601, Japan \\ E-mail: narama@nagoya-u.jp \\ ${ }^{2}$ Department of Earth System Science, Fukuoka University, Fukuoka 814-0180, Japan
}

\begin{abstract}
Moraines in five valleys of the Turkestan range of the Pamir-Alay, Kyrgyz Republic, were analyzed based on their geographical position and elevation, morphology and ecological characteristics. The moraines represent four glacial advances: Turkestan Stage I, during the last glacial; Stage II, during the late Holocene; Stage III, during the Little Ice Age (AD 1400-1900); and Stage IV, during the 20th century. In Turkestan Stage I, the glaciers expanded to about 5-10 km from their present termini during marine isotope stage (MIS) 2. Radiocarbon ages for several soil layers buried in a lateral moraine of the Asan-Usin glacier frontal area indicate that glaciers shrank or stagnated between at least $\sim 48$ and $42 \mathrm{kyr} \mathrm{BP}$, during the warm climate of mid-MIS 3 . These findings suggest that the glacier expansion in mid-MIS 3 was relatively small compared to the glacier expansion of MIS 2 during the last glacial.
\end{abstract}

\section{INTRODUCTION}

The continental ice sheets in the Arctic region reached their maximum extension in marine isotope stage (MIS) 2 during the last glacial (e.g. Dyke and Prest, 1987), while there was significant variability among mountain glaciers in other areas of the world (e.g. Derbyshire and others, 1991; Gillespie and Molnar, 1995). In the Karakoram mountains of south Asia, where the climate is influenced by the Indian monsoon and mid-latitude westerlies (Yasunari and Fujii, 1983), the glacier expansion during MIS 3-4 exceeded that of MIS 2 (Phillips and others, 2000; Richards and others, 2000; Owen and others, 2002a,b). This suggests that glaciers in Asian mountains responded differently to local climate changes.

In the western and northern parts of the central Asian mountains (in the former USSR), where glaciers accumulate mass from westerly systems in winter and spring (Aizen and others, 1995), past glacier histories have been reconstructed using relative dating methods such as moraine elevations (Velichko and Lebedeva, 1974; Grosswald and others, 1994; Meiners, 1997; Heuberger and Sgibnev, 1998) and soil development (Bäumler and others, 1999; Zech and others, 2000). Recently, Zech and others (2005) reported on the chronology of glaciers in the central Pamirs based on the cosmogenic ${ }^{10} \mathrm{Be}$ surface exposure ages. Absolute dating is a critical component of glacier chronologies in the central Asian mountains, which have a complex climate environment. We report evidence for glacier oscillation throughout the late Quaternary in the Turkestan range of the Pamir-Alay region of the Kyrgyz Republic, based on radiocarbon dating.

\section{RESEARCH AREA}

The research area is in the north flank of the Turkestan range of the Pamir-Alay, in the southwestern part of the Kyrgyz Republic (Fig. 1a). The Turkestan range is in the west margin of the Pamir-Alay mountains, and has elevations of about $4000-6000 \mathrm{~m}$. The range is the border between the Tajikistan and Kyrgyz Republics, and the region is part of the Syr Darya (north flank) and Amu Darya (south flank) drainage systems. Glacier termini on the north flank of the Turkestan range have elevations of $2800-3800 \mathrm{~m}$, and their equilibrium-line altitudes range between 3800 and $4000 \mathrm{~m}$ (Petrov and Schetinnikov, 1974). The terminal parts of most valley glaciers are covered with mantles of debris originating from the steep slopes of the large neighboring walls. The ranges within the Pamir-Alay, which consist of sediments
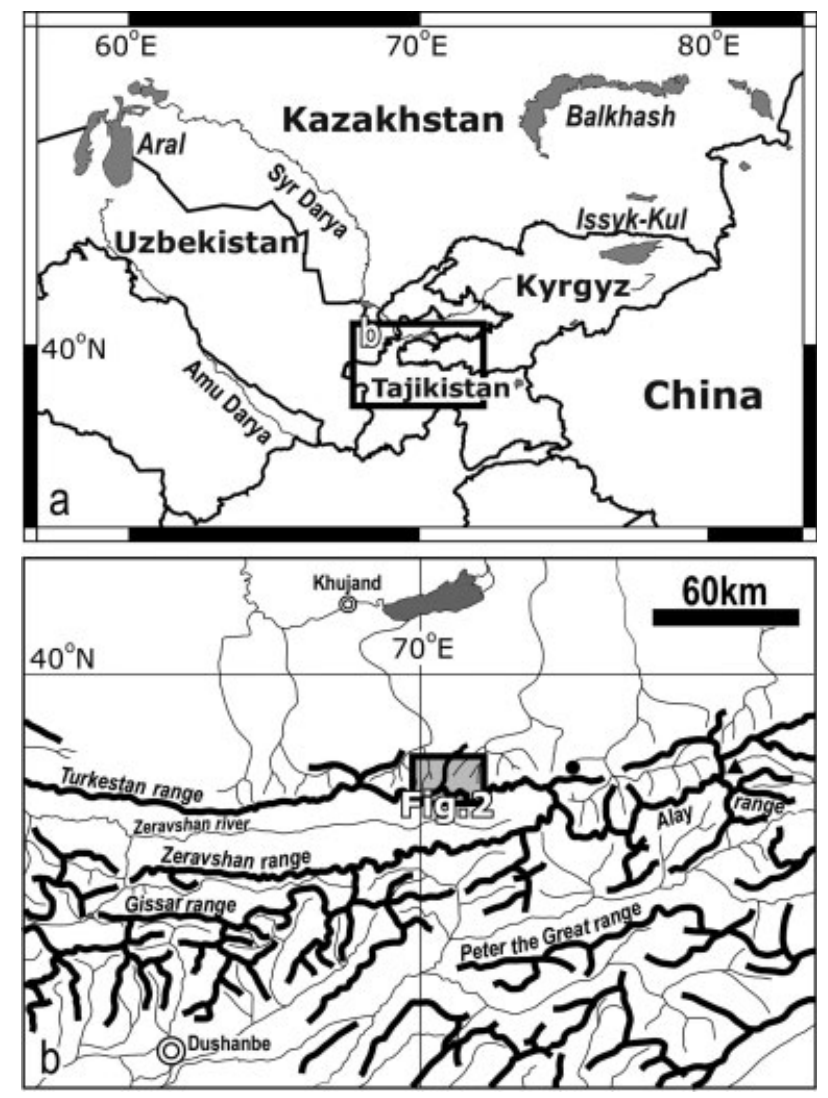

Fig. 1. The study area. (a) The Pamir-Alay, located in the southwestern corner of the Kyrgyz Republic, in central Asia. (b) The study area, on the north flank of the Turkestan range, in the headwaters of the Syr Darya river. Thick lines indicate mountain ranges, and thin lines show the river system. The rectangular area is the study area, which is enlarged in Figure 2. •: Location of Raygorodskogo glacier. A: Abramov glacier meteorological station. 


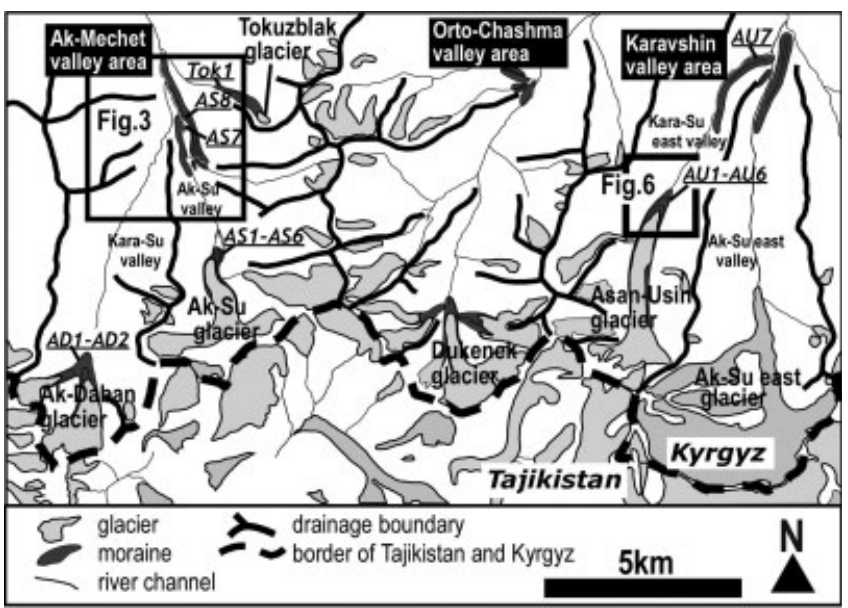

Fig. 2. Moraines of the Ak-Mechet (Kara-Su and Ak-Su), OrtoChashma and Karavshin (Kara-Su east and Ak-Su east) valley areas.

from the Paleozoic, were formed by the activity of eastwest-trending faults, such as the trans-Alay overthrust (Burtman and Molnar, 1993). The main rock types in the glaciated areas are granite and metamorphic rocks.

The Turkestan range in the western margin of the PamirAlay is strongly influenced by westerly winds from winter to spring, when the region receives much precipitation. At the Abramov glacier meteorological station in the Alay range (3837 m a.s.l.; Fig. 1b), the average annual temperature over the period $1968-94$ was $-4.2^{\circ} \mathrm{C}$ and the annual precipitation was $1004.0 \mathrm{~mm}$ (Pertziger, 1996). In the study area, there are two pairs of valleys, named Kara-Su and Ak-Su; hereafter, the terms Kara-Su and Ak-Su valleys refer to the valleys in the AkMechet valley area, and the terms Kara-Su east and Ak-Su east valleys refer to the valleys in the Karavshin valley area (Fig. 2).

\section{METHODS}

The distribution of moraines and proglacial landforms in the Ak-Mechet, Orto-Chashma and Karavshin valley areas in the north flank of the Turkestan range was mapped using $1: 100000$ topographic maps during field observations in summer 1999 (Fig. 2). Moraines were classified temporally using their geographical (position and elevation), morphological and ecological (vegetation cover and lichenometry) characteristics. For Holocene moraines, the degree of vegetation cover is useful; for example, there are differences in both the presence and height of Juniperus turkestanica trees between the late-Holocene and Little Ice Age moraines in the Turkestan range (Narama, 2002). Lichenometry is also a useful tool; the existence of Rhizocarpon sp. was confirmed on the moraines. Based on these indices, the moraines in these valleys were classified into several stages and named using local geographic names. Moraines were also given names such as AD for Ak-Daban glacier, and numbered accordingly (e.g. AD1 and AD2).

Sedimentary surveys in exposures of moraine and river terrace included exposure sketches, measurements of the fabric and size distributions of 50 clasts, roundness using Krunbein's index (1941), and grain-size analysis of the matrix using a laser-scattering particle size analysis machine (SALD3000J, Shimazu). Sedimentary facies codes are those of Eyles and others (1983). Soil color was determined using the Munsell soil-color chart.

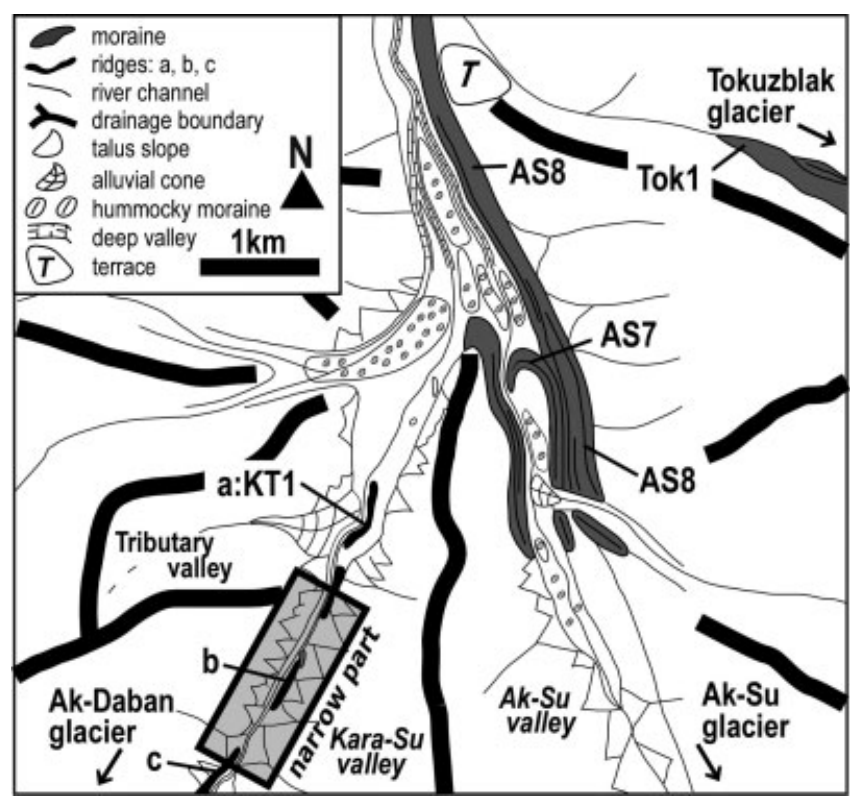

Fig. 3. The area around the confluence of the Kara-Su and Ak-Su valleys. The map covers the area shown in Figure 2. Hummocky moraines are distributed on the U-shaped valley bottom.

To determine the timing of glacier advances, organic material from moraine and terrace, such as buried soil (not including dead carbon as soil carbonate) and dead wood, was collected for radiocarbon dating. A humin fraction of soil sample and wood was obtained using acid-alkali-acid (AAA) treatments. The organic carbon and nitrogen contents were measured for a humin fraction, using a $\mathrm{CN}$ analyzer (MT-700, Yanaco). The $\mathrm{CO}_{2}$ from a humin fraction was reduced to graphite catalytically on Fe powder with $\mathrm{H}_{2}$ in a sealed Vycor tube (Kitagawa and others, 1993). We used a HVEE Tandetron accelerator mass spectrometer at Nagoya University to make radiocarbon measurements of graphite targets with NIST oxalic acid (HoxlI) as standards (Nakamura and others, 2000). The ${ }^{14} \mathrm{C}$ background level evaluated using commercial graphite powder corresponds to an equivalent radiocarbon date of $48970 \pm 410$ years BP (NUTA2-1937). The background was subtracted in this study. We corrected for carbon isotopic fractionation using $\delta{ }^{13} \mathrm{C}_{\text {PDB }}$. This radiocarbon age can be tentatively calibrated to the calendar year, based on the calibration datasets obtained from the programs Oxcal 3.10 (INTCAL04; Bronk Ramsey, 2001) and CalPal (Cologne Radiocarbon Calibration and Paleoclimate Research Package) on the website (http://www.calpal.de).

\section{RESULTS}

\section{Ak-Mechet valley area}

\section{Kara-Su valley}

Moraines AD1 and AD2 are located within $1 \mathrm{~km}$ of the AkDaban glacier terminus $\left(39^{\circ} 34^{\prime} \mathrm{N}, 70^{\circ} 00^{\prime} \mathrm{E} ; 3580 \mathrm{~m}\right.$ a.s.l.) in the Kara-Su valley (Fig. 2). Moraine AD1 (3520 ma.s.l.) consists of small mounds, some distributed randomly and some in fragmentary ridges, reflecting the former extent of the glacier. These mounds consist of fresh angular debris and have sparse grass cover and no lichen. Lateral moraine AD2 (3480 $\mathrm{m}$ a.s.I.) on the left bank has grass, and a stream dissects its terminal part, which is $30 \mathrm{~m}$ higher than the riverbed. 


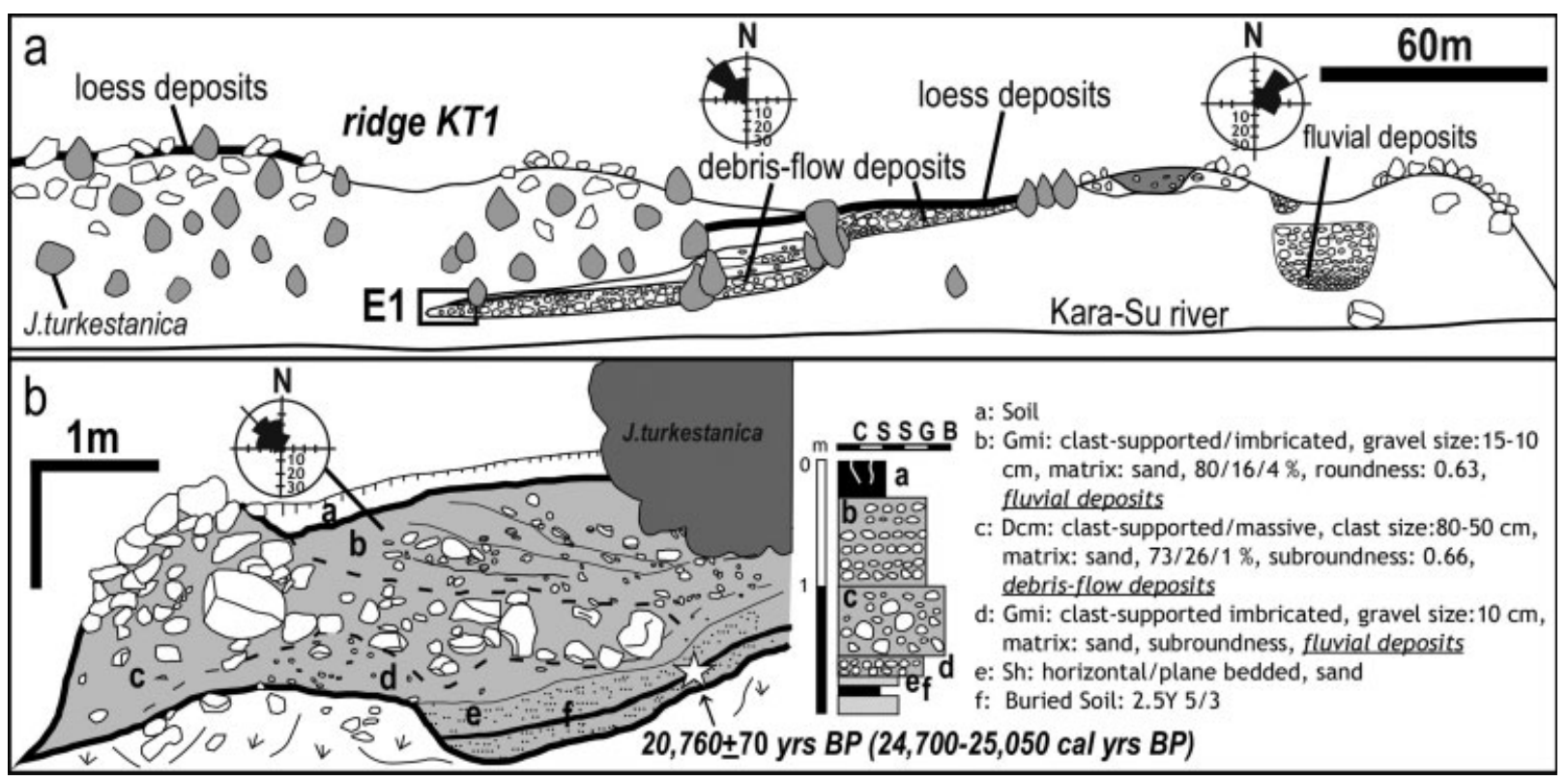

Fig. 4. Ridge KT1 in the Kara-Su valley. (a) Profile of ridge KT1 (a in Fig. 3). The rectangular box is exposure E1, which is enlarged in (b). (b) Sketch of exposure E1 at the bottom of a mound in ridge KT1. Particle size of the profile is C = clay, $\mathrm{S}=$ silt, $\mathrm{S}=\mathrm{sand}$, G = gravel, $\mathrm{B}=$ boulder. Matrix is sand/silt/clay $(\%)$.

Sediments in older landforms in the Kara-Su valley Figure 3 shows a large-scale map of the Kara-Su and Ak-Su valleys (location in Fig. 2). There are three ridges in the KaraSu valley, marked a-c. Mound ridge KT1 (Kara-Su tributary; $2820 \mathrm{~m}$ a.s.l.) is $20-25 \mathrm{~m}$ above the riverbed and is located downstream on the Kara-Su valley bottom (a in Fig. 3). The ridge originated from a tributary valley, but it has been dissected by the water of the Kara-Su river, exposing its constituent sediment. There are sparse angular boulders and J. turkestanica bushes on ridge KT1 (Fig. 4a). The ridge is a complex landform, composed of huge boulders, debris-flow and fluvial and mass-movement deposits. Deposits of massive angular boulders in a sandy matrix include clay patches in the deposits. The surface soil layer (A/B horizon) is $20-40 \mathrm{~cm}$ thick over the loess deposits (C horizon) which are $20-50 \mathrm{~cm}$ thick, and carbonate (Ckb horizon) layers. The tributary valley of the Kara-Su valley is wide and has a gentle slope, but has no glacier at present. Figure $4 \mathrm{~b}$ shows exposure E1 at the bottom of ridge KT1 (box in Fig. 4a). Exposure E1 consists of fluvial deposits (layers b and d (L-b and L-d)), a debris flow (L-C) and sand layers (L-e). The paleocurrent of fluvial deposit (L-b) shows the present current direction. Within the $30 \mathrm{~cm}$ thick sand layer (L-e), there is a $7 \mathrm{~cm}$ thick soil layer (L-f: Ab horizon). The radiocarbon age of the upper $2 \mathrm{~cm}$ of this buried soil is $20760 \pm 70$ years BP (NUTA2-1905), indicating that the ridge deposits are younger than this age (Table 1 ). This radiocarbon age can be calibrated to 24 700-25 050 cal. years BP.

The $2 \mathrm{~km}$ long narrow part in the Kara-Su valley (Fig. 3) contains terraces, talus slopes (younger and older) and debris-block-stream sediments. A terrace (2980 ma.s.l.) on the right bank in the upper region (b in Fig. 3) is $500 \mathrm{~m}$ long and $15 \mathrm{~m}$ above the riverbed. The terrace is covered with $5 \mathrm{~m}$ high J. turkestanica trees and large boulders. Debrisflow deposits, subrounded to rounded boulders, and fluvial deposits with bedding and sorting were observed in several exposures of the terrace. Figure 5a shows that exposure E2 in the terrace is composed of subangular and subrounded boulders in a sandy matrix (L-b and L-e), intercalated thin sand (L-c) and soil layers (L-d: Ab horizon). The thin sand

Table 1. Radiocarbon of organic materials which were sampled from moraines and river terrace

\begin{tabular}{|c|c|c|c|c|c|}
\hline Valley & Sampling site & Sample material & $\begin{array}{l}{ }^{14} \mathrm{C} \text { age } \\
\text { years BP }\end{array}$ & Calendar age & Laboratory No. \\
\hline Ak-Su & Moraine Ak6 & Wood & $470 \pm 15$ & AD $1435 \pm 10$ & NUTA2-636 \\
\hline Tokzbrak & Moraine Tk2 & Wood & $370 \pm 15$ & $A D 1490 \pm 30$ & NUTA2-632 \\
\hline \multirow[t]{3}{*}{ Kara-Su } & Ridge KT1 & Soil & $20760 \pm 70$ & $24840 \pm 319$ cal. years BP & NUTA2-1905 \\
\hline & River terrace & Soil & $36900 \pm 210$ & $42156 \pm 181$ cal. years BP & NUTA2-1896 \\
\hline & Talus slope & Soil & $10840 \pm 50$ & $12806 \pm 44$ cal. years BP & Beta-177604 \\
\hline \multirow[t]{5}{*}{ Kara-Su east } & Moraine AU6 & Soil & $>48190$ & & NUTA2-1897 \\
\hline & Moraine AU6 & Soil & $43760 \pm 390$ & $46692 \pm 1444$ cal. years BP & NUTA2-1904 \\
\hline & Moraine AU6 & Soil & $43230 \pm 380$ & $46195 \pm 1375$ cal.years BP & NUTA2-1899 \\
\hline & Moraine AU6 & Soil & $36050 \pm 210$ & $41861 \pm 165$ cal.years BP & NUTA2-1900 \\
\hline & Moraine AU5 & Wood & $250 \pm 15$ & $\mathrm{AD} 1655 \pm 10$ & NUTA2-633 \\
\hline
\end{tabular}




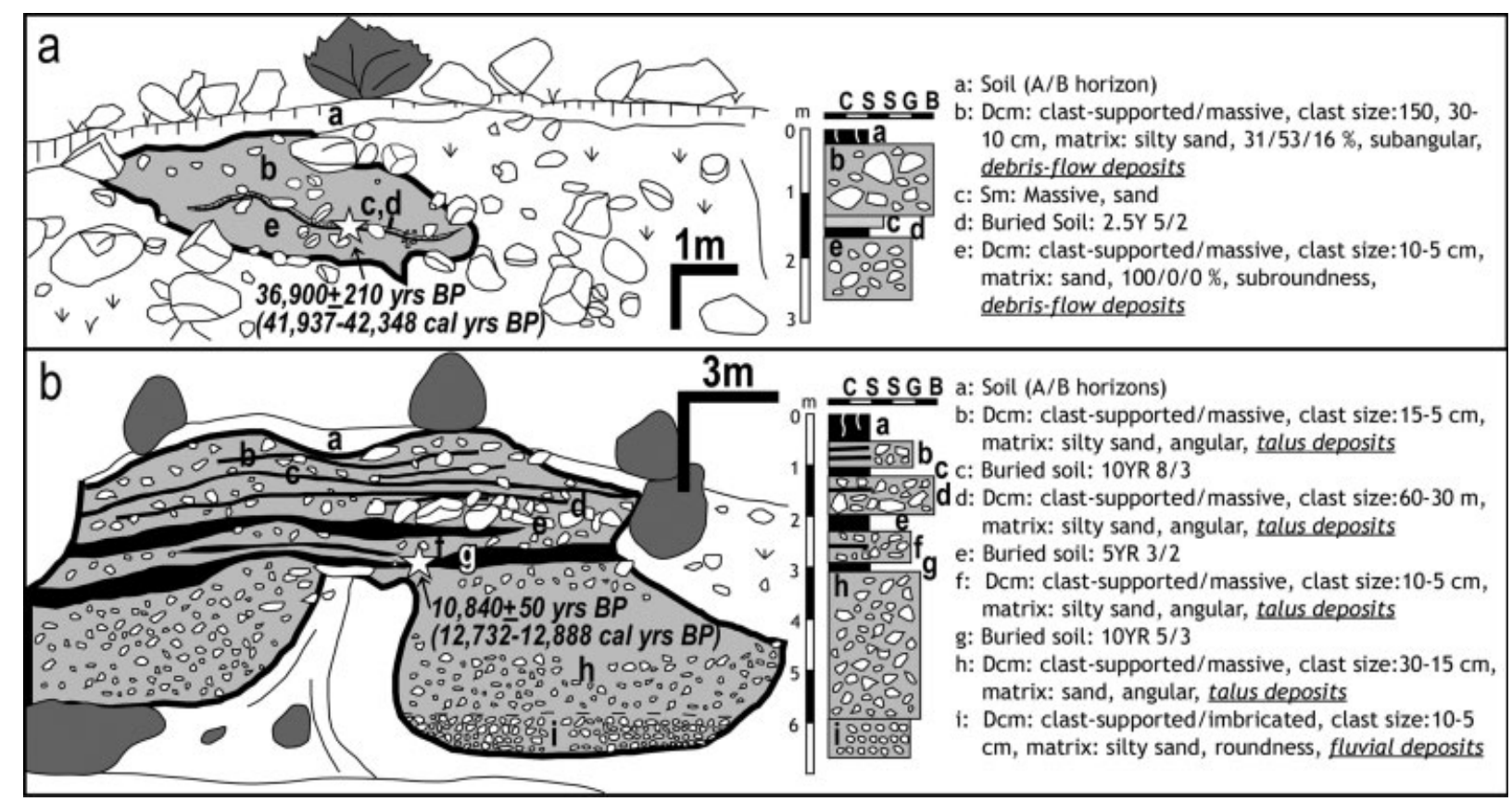

Fig. 5. Sketches of exposures E2 and E3 in the narrow part of the Kara-Su valley. (a) Exposure E2 is top of terrace ridge (b in Fig. 3). (b) Exposure E3 is composed of talus deposits in the ridge (c in Fig. 3).

layer on the soil layer shows that the sedimentary structures remained combined with other deposits, and were unchanged after the subsequent deposits. The uppermost $2 \mathrm{~cm}$ of buried soil has a radiocarbon age of $36900 \pm 210$ years BP (41 937-42 348 cal. years BP, NUTA2-1896; Table 1). The age indicates that Ak-Daban glacier was located upstream from this point after deposition of the debris flow.

On the left, the upstream bank of the narrow part of the valley, $250 \mathrm{~m}$ wide exposures of older talus slopes (3050 ma.s.l.) occur continuously (c in Fig. 3). The slope advances to the central position on the valley bottom. Exposure E3 is $10 \mathrm{~m}$ high and is composed of soil, clast and fluvial layers (Fig. 5b). Several clast layers that consist of angular clasts of sedimentary rock within a silty matrix are talus deposits. The radiocarbon age of the uppermost $2 \mathrm{~cm}$ of soil in the $20-30 \mathrm{~cm}$ thick soil layer $(\mathrm{L}-\mathrm{g})$ is $10840 \pm 50$ years BP $(12732-12888$ cal. years BP, Beta177604; Table 1). This soil layer has a horizontal structure, and this stabilized landform was maintained after the deposits. The age indicates that these thick talus deposits have accumulated since the late glacial, and Ak-Daban glacier was located upstream during this period.

\section{Ak-Su valley}

There are eight moraines, AS1-AS8, in the Ak-Su valley (AkSu glacier terminus: $39^{\circ} 36^{\prime} \mathrm{N}, 70^{\circ} 04^{\prime} \mathrm{E}$; $3400 \mathrm{~m}$ a.s.I.) (Fig. 2). Lateral moraine AS8 stretches from 2350-2400 to $2900 \mathrm{~m}$ a.s.l. and is about $70 \mathrm{~m}$ above the riverbed (Fig. 3). The surface is covered with dense J. turkestanica trees, and the subangular boulders on the exposed surface are minor. Moraine AS7 is covered with grass and sparse $6 \mathrm{~m}$ high J. turkestanica trees, is located at $2800 \mathrm{~m}$ a.s.l. upstream from moraine AS8 and is $40 \mathrm{~m}$ above the riverbed. Hummocky moraines are abundant in the area delineated by these lateral moraines at 2550-2900 m a.s.l.

Moraines AS1-AS6 (3150-3280 m a.s.l.) are located sideby-side within $1.2 \mathrm{~km}$ downstream of the glacier terminus and are 5-30 $\mathrm{m}$ above the riverbed (Fig. 2). They are small ridges, and the depressions between them are filled with glacial deposits. Although these moraines have similar grass coverage, they have different amounts of lichen growth, which reflects differences in their ages. Dead J. turkestanica trees are present under the large boulders of moraine AS6. The wood indicates that trees once grew in the glacier frontal area, but boulders of moraine AS6 destroyed the trees during glacier expansion. The radiocarbon age obtained from the outer rings of a piece of wood from this moraine is $470 \pm 15$ years BP (AD 1425-1445, NUTA2-636; Table 1). The age indicates that moraine AS6 formed during the maximum expansion of Ak-Su glacier during the Little Ice Age.

Moraine Tok1 (Tokuzblak glacier terminus: $39^{\circ} 39^{\prime} \mathrm{N}$, $70^{\circ} 05^{\prime} \mathrm{E} ; 3820 \mathrm{~m}$ a.s.l.) of the Tokuzblak glacier frontal area is located in a tributary valley on the right bank of the Ak-Mechet valley (Figs 2 and 3). Dead J. turkestanica trees are present under the large boulders of moraine Tok1. This moraine has only sparse grass cover. The radiocarbon age for the outer tree-rings of a piece of a dead tree from Tok1 terminal moraine (3120 ma.s.l.) is $370 \pm 15$ years BP (AD 1460-1520, NUTA2-632; Table 1). The dead trees indicate that the moraine boulders were deposited on living trees in the glacier frontal area during the glacier advance. The age indicates that moraine Tok1 formed during the maximum extension of Tokuzblak glacier in the Little Ice Age.

\section{Karavshin valley area}

\section{Moraines and moraine sediment in the Kara-Su east valley}

Kara-Su east and Ak-Su east valleys are upstream from the Karavshin valley (Fig. 2). There are seven moraines, AU1AU7, in the Kara-Su east valley (Asan-Usin glacier terminus: $39^{\circ} 37^{\prime} \mathrm{N}, 70^{\circ} 15^{\prime} \mathrm{E} ; 3160 \mathrm{~m}$ a.s.l.). The large lateral moraine AU7 (2400 ma.s.l.), which is on the right bank $80-100 \mathrm{~m}$ above the riverbed, is well preserved. The terminal part of 


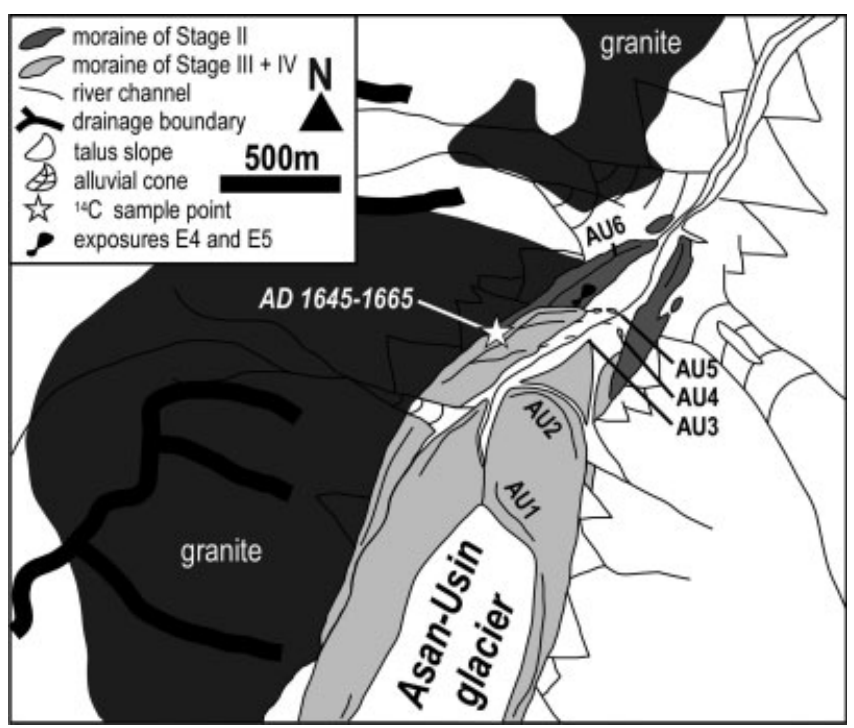

Fig. 6. The Asan-Usin glacier frontal area. The area is shown in Figure 2. Moraines AU1-AU6 are within $1.2 \mathrm{~km}$ downstream of the Asan-Usin glacier terminus.

the lateral moraine is located at the confluence with the moraine of the Ak-Su east valley. Moraine AU7 has a thick soil layer and is densely covered with tall J. turkestanica trees. Several small terraces exist inside the moraine.

Small moraines AU1-AU6 are located in the Asan-Usin glacier frontal area in the Kara-Su east valley (Fig. 6). Moraines AU4-AU6 (2950-3005 ma.s.I.) are located $0.6-1.2 \mathrm{~km}$ downstream from the glacier terminus and are $30 \mathrm{~m}$ above the riverbed. Alluvial deposits from a small tributary valley cover part of the terminal moraine of moraine AU6. Small talus slopes on the left-side valley, supplied from granite bedrock, cover the outside of lateral moraines AU5-AU6. These moraines are composed of slate rocks, identical to the debris on Asan-Usin glacier. Moraine AU6 is covered with J. turkestanica trees up to $6 \mathrm{~m}$ high (Fig. 7). By contrast, grasses such as Ciperiuf and Deschampsia are sparse on moraines AU4 and AU5, and a soil layer has only formed incipiently. Dead, down-thrown or buried J. turkestanica trees are present at the margin of moraines AU5 and AU6 because the sediments of moraine AU5 (grass) overlie part of lateral moraine AU6 (trees). These dead trees indicate that J. turkestanica trees growing on moraine AU6 were plowed down by the deposits of moraine AU5 during glacier expansion. The radiocarbon age obtained from the outer rings of a tree is $250 \pm 15$ years BP (AD 1645-65, NUTA2-633; Table 1), which shows that moraine AU5 formed during the maximum expansion of Asan-Usin glacier during the Little Ice Age. The difference in the degree and type of vegetation cover on moraines AU5 and AU6 suggests that moraine AU6 is an older moraine that formed before the Little Ice Age.

There are two exposures, E4 and E5, on the inside of moraine AU6 on the left bank (Figs 6 and 7). The facies of exposure E4 (a in Fig. 7) shows a cross-profile of the lateral moraine to the glacier flow (Fig. 8a). The material consists of angular slate boulders and is divided into five layers ( $\mathrm{L}-\mathrm{a}, \mathrm{C}$, $\mathrm{e}, \mathrm{g}$ and $\mathrm{i}$ ), including four buried soil layers (Ab horizon). Clast diameters differ slightly in each layer, and the buried soil layers slope towards the outside of the lateral moraine. The sedimentary structures indicate that a sequence of lateral moraines occurred, each one supplying supraglacial

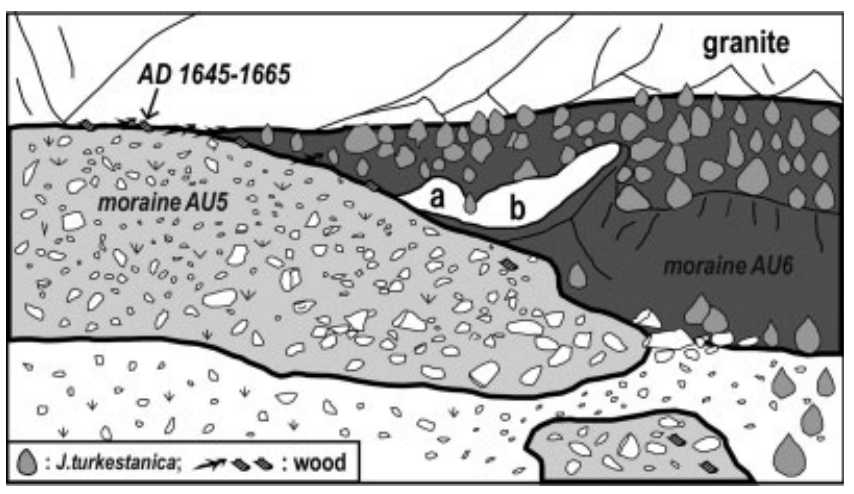

Fig. 7. The location of exposures E4 (a) and E5 (b) in moraine AU6, where $J$. turkestanica trees grow. Because the deposits of moraine AU5 cover moraine AU6, dead and broken J. turkestanica trees were observed at the border of moraines AU5 and AU6. Radiocarbon age of a dead broken tree is AD $1655 \pm 10$.

materials from the glacier surface (Humlum, 1977; Bennett and Glasser, 1996). The clasts of the lateral moraine are slate, identical to the debris on the glacier, and the moraine deposits are not composed of any granitic clasts from the left-side valley wall. The uppermost buried soil (L-b) is radiocarbon-dated as being >48 190 years BP (NUTA2-1897; Table 1).

Exposure E5 of moraine AU6 (b in Fig. 7) has a profile parallel to the glacier flow (Fig. 8b). Exposure E5 is also composed of angular slate boulders. Horizontal, thin buried soil layers (Ab horizon) were observed in the exposure in the upstream and downstream sections. The clast layers consist of massive- or low-sorting, angular boulders with clast-supported deposits. The size of the material varies widely, with many huge boulders, reflecting various depositional processes that included supraglacial melt-out of unsorted material (Humlum, 1977; Small, 1983; Lyså and Lønne, 2001). Some of the buried soil layers consist of alternating soil and sand layers. The uppermost $2 \mathrm{~cm}$ of the middle buried soil layer (L-k) in the upstream section has a radiocarbon age of $36050 \pm 210$ years $\mathrm{BP}$ (41 647-42 013 cal. years BP, NUTA2-1900; Table 1). The uppermost $2 \mathrm{~cm}$ of the two buried soil layers (L-d and L-h) in the downstream section has radiocarbon ages of $43230 \pm 380$ years BP (45 280-48 146 cal. years BP, NUTA21899; Table 1) and $43760 \pm 390$ years BP (45 64048574 cal. years BP, NUTA2-1904; Table 1), respectively. These buried soil layers in exposures E4 and E5 have ages that are near the maximum age that the radiocarbon method can detect. The relationship of 45-48 kyr BP and 46-49 kyr BP of soil layers (L-d and L-h) in exposure E5 was consistent with the stratigraphic sequence. These ages show that the sediment of moraine AU6 was composed of very old glacial deposits, and that some of the sediment in moraine AU6 was deposited in mid-MIS3 during several glacial advances. However, moraine AU6 remains a part of the terminal moraine that is located $1.2 \mathrm{~km}$ downstream from the glacier terminus.

Moraines AU1-AU3 (3005-3150 ma.s.l.) are small ridges in the glacier frontal area, and consist of fresh debris with no vegetation. Although moraine AU3 lacks obvious terminal parts, its expansion range is shown by the distribution of small mounds of angular clasts that cover the flat riverbed. 


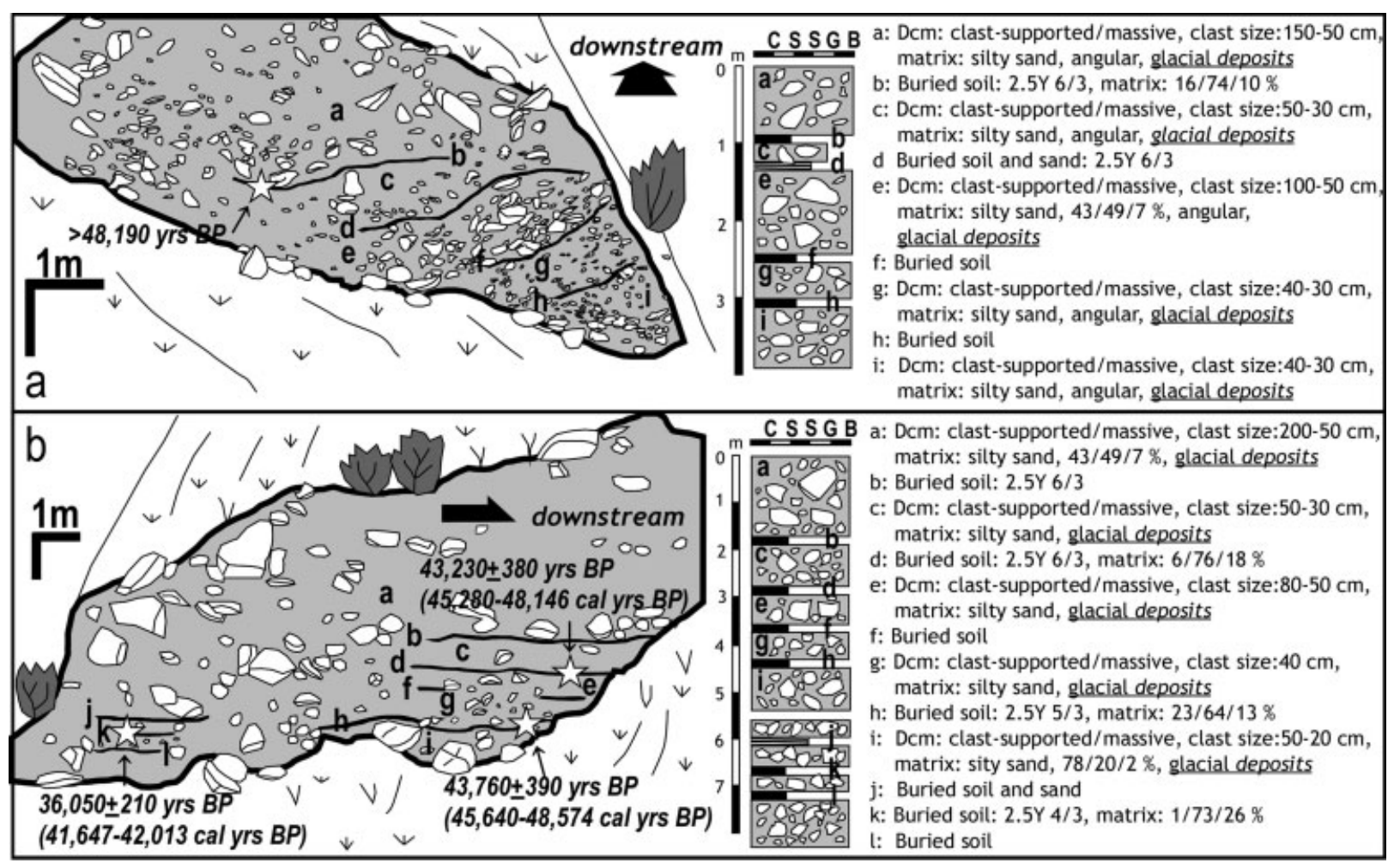

Fig. 8. Sketches of two exposures E4 (a in Fig. 7) and E5 (b in Fig. 7) of moraine AU6. (a) E4 shows a cross-profile of the lateral moraine to the glacier flow. (b) E5 shows a longitudinal profile of the lateral moraine.

\section{DISCUSSION}

\section{Glacier variations in Turkestan Stage I, during the last glacial}

The moraines in each valley can be divided into upstream and downstream groups. The upstream group consists of those moraines that are within $2 \mathrm{~km}$ of the glacier termini (AD1-AD2: Kara-Su valley; AS1-AS6: Ak-Su valley; Tok1: tributary valley of Ak-Mechet; AU1-AU6: Kara-Su east valley). The downstream group consists of moraines that are $>5 \mathrm{~km}$ from the glacier termini (AS7-AS8, AU7). The elevation difference between glacier termini and associated moraines is about $100-200 \mathrm{~m}$ for the upstream group and $600-1000 \mathrm{~m}$ for the downstream group. The relative height of moraines above the riverbed is $5-30 \mathrm{~m}$ for the upstream group and $40-100 \mathrm{~m}$ for the downstream group. The moraines of the upstream group were subdivided into three groups according to the degree of vegetation cover: those lacking vegetation (AD1, AS1, AU1-3), those with sparse vegetation cover or with dwarf J. turkestanica (AD2, AS2-6, Tok1, AU4-5), and those with tall J. turkestanica and Rhizocarpon sp. (AU6). Using these criteria, the moraines were grouped into four stages, called Turkestan Stages I-IV.

Turkestan Stage I moraines formed during the last glacial. Ridge KT1 (2820 ma.s.l.), composed of huge boulders and mass-movement deposits, received material from the tributary valley of the Kara-Su valley (a in Fig. 3). The radiocarbon dating of the buried soil beneath the ridge indicates that it formed after $25 \mathrm{kyr} B \mathrm{BP}$ (Fig. 4). The ridge surface is covered with well-developed soil, thick loess and dwarf J. turkestanica. The well-defined moraines AS7-AS8 and AU7 belong to Turkestan Stage I and have the same characteristics as ridge $\mathrm{KT} 1$; they are covered with thick soil, contain loess deposits and have dense vegetation consisting of high grass and trees. These moraines clearly differ from those of Turkestan Stage II. Moraine AU6, which belongs to Turkestan Stage II, exhibits a $20-30 \mathrm{~cm}$ soil layer with trees, but sparse grass, and lacks loess. It is probable that moraines AS7, AS8 and AU7, which belong to Turkestan Stage I, are about the same age as ridge KT1 and were deposited in MIS 2. These relative elevations $(\sim 600-1000 \mathrm{~m})$ between the glacier termini and moraines are similar to the relative elevation $(1150 \mathrm{~m})$ for MIS 2 moraine in the Alay range in the Pamir-Alay (Zech and others, 2000). For that area, Zech and others (2000) reported that Abramov glacier advanced from 16 to $24 \mathrm{kyr}$ BP, based on the radiocarbon ages of buried soils from a lateral moraine near the glacier. In the central Pamirs, cosmogenic ${ }^{10} \mathrm{Be}$ dating of moraines shows that glaciers advanced during MIS 2 (Zech and others, 2005). During MIS 2, in the area of the present study, glaciers advanced to about $10 \mathrm{~km}$ downstream from their presentday termini. In the middle part of the Kara-Su valley, however, these non-glacial deposits of the terrace and talus slope indicate that the Ak-Daban glacier expansion was not as significant as that of Ak-Su and Asan-Usin glaciers in the interval 13-42 kyr BP.

\section{Holocene glacier variation in Turkestan Stages II-IV}

Turkestan Stage II moraines formed during the late Holocene. Moraine AU6, in the Asan-Usin glacier frontal area of the Kara-Su east valley, has deposits dating from mid-MIS 3 (Fig. 8). It is likely, however, that the present shape of moraine AU6 formed after MIS 2, because it contains part of a terminal moraine that is located $1.2 \mathrm{~km}$ from the glacier terminus, and the large moraine AU7 (Turkestan Stage I) in MIS 2 is located $7 \mathrm{~km}$ downstream from the glacier terminus. In the glacier frontal area, moraine AU6 (trees) has 
considerably better-developed vegetation than moraine AU5 (grass only). This vegetation pattern was also documented in moraines of the nearby Raygorodskogo glacier (Fig. 1b), which was dated to the late Holocene (Narama, 2002). A younger terminal moraine $(2700 \mathrm{~m}$ a.s.l.), $1 \mathrm{~km}$ downstream from the glacier terminus $\left(39^{\circ} 39^{\prime} \mathrm{N}, 70^{\circ} 46^{\prime} \mathrm{E} ; 2780 \mathrm{~m}\right.$ a.s.I. $)$, is covered by grass and overlies part of an older terminal moraine $(2680$ ma.s.l.) that is covered by trees. The two moraines date to AD 1520-90 (Little Ice Age) and AD 250440 (late Holocene). Tree rings of $6 \mathrm{~m}$ high J. turkestanica trees on the late-Holocene moraine indicate ages of 388408 years. The radiocarbon age of the younger moraine was obtained from dead trees present within the younger moraine debris. Both the small glacier expansion and the presence of a moraine with dense vegetation in the glacier frontal area indicate that moraine AU6 formed by the AsanUsin glacier expansion during the late Holocene. Evidence of small glacier expansion in the late Holocene has also been found in the Tien Shan and the Pamir-Alay mountains (Savoskul and Solomina, 1996; Zech and others, 2000).

Moraines of Turkestan Stage III (Little Ice Age; AD 14001900) are located in the glacier frontal area and have sparse grass cover. Ak-Su, Tokuzblak and Asan-Usin glaciers advanced over forested proglacial areas, such that toppled trees were overlain by moraine material on the downstream sides of moraines. Three wood samples obtained from moraines AS6, Tok1 and AU5 had radiocarbon ages between AD 1425-45 and 1645-65. A similar radiocarbon age (AD 1520-90) was obtained for wood from the Raygorodskogo glacier frontal moraine in the Turkestan range (Narama, 2002). These radiocarbon dates show that the Turkestan Stage III moraines formed during the Little Ice Age.

Turkestan Stage IV took place in the 20th century. The moraines in this stage have either no lichen or lichens with very small diameters. Some moraines can therefore be dated using observational records of terminal variations since the 1900s, and using the US Corona satellite images taken in the 1960s and 1970s. Narama (2001) described detailed fluctuations of Pamir-Alay glaciers in the 1900s using observational data.

\section{Glacier variation and paleoclimate in MIS 3}

The sedimentary succession exposed in lateral moraine AU6 in the Kara-Su east valley reveals the history of Asan-Usin glacier. Lateral moraines have been used to reconstruct glacier variations in the Himalaya, Karakoram and New Zealand (Gellatly and others, 1985; Röthlisberger and Geyh, 1985) because their sediment commonly contains buried soil layers and is structurally stable. Figure 9 shows a schematic cross-section of Asan-Usin glacier and lateral moraines AU5 and AU6. Undisturbed, buried soil layers in the exposures indicate that pre-existing moraine deposits were overlain by material deposited from the glacier surface during glacier advances. Radiocarbon dates for these multiple buried soils suggest that they formed from $>48$ to 42 kyr BP. Such thick buried soil layers are records of glacier stagnation or retreat under warm climatic conditions. The repeated intercalation of soil layers and glacial deposits suggests that phases of glacier stagnation or retreat were frequently interrupted by glacier advances during midMIS 3. Sediment layers are thin, and the height of the lateral moraine is significantly less than that of moraine AU7 (MIS 2), indicating that glaciers were comparatively small during the last glacial. Significant warm intervals occurred

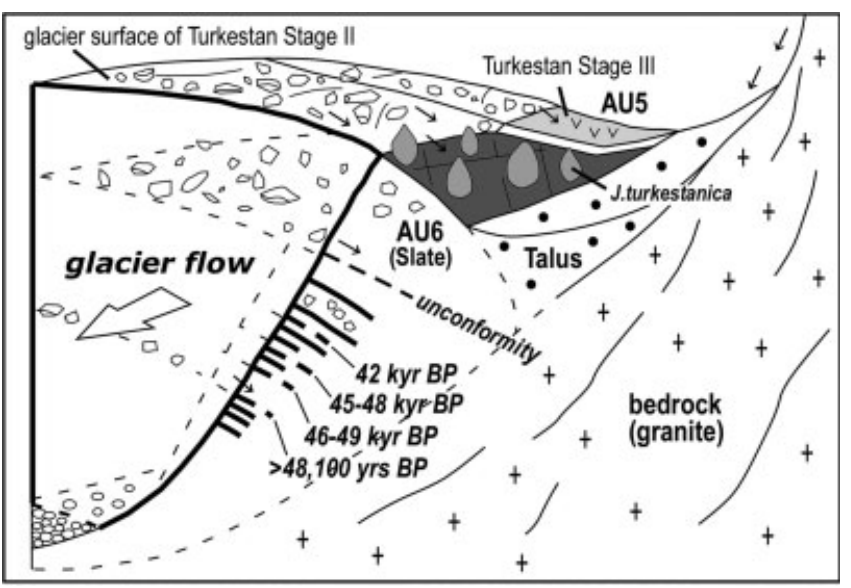

Fig. 9. Schematic cross-section of AU5 and AU6 lateral moraines in the Asan-Usin glacier frontal area. The moraine is composed of older and younger deposits. Unconformity of younger and older deposit layers was not exposed on moraine AU6.

during mid-MIS 3. Paleosol formation during MIS 3 was also reported from loess-paleosol successions in central China (Rost, 2000). In contrast, in the Karakoram mountains, glacier expansion in the early to mid-MIS 3 occurred in the Swat (38 and 59 kyr BP), Chitral (MIS 3), Hunza (4355 kyr BP) and Nanga Parbat (30-60 kyr BP) areas. The expansions in MIS 3-4 were on a larger scale than those of MIS 2 (Phillips and others, 2000; Richards and others, 2000; Owen and others, 2002a, b). Glacier extension has also been reported in MIS 4 and $\sim 40 \mathrm{kyr}$ BP (early to midMIS 3) in the central Pamirs, near the Karakoram, and tentatively attributed to the influence of the Indian monsoon and westerlies (Zech and others, 2005). Based on thermoluminescence ages of loess deposits on moraine in southern Tibet, Lehmkuhl (1998) suggested that the maximum glacial extent during the last glacial occurred during MIS 4. There is a possiblity that glacier advances during mid-MIS 3 in the Pamir-Alay differed from those in mountain areas that are more strongly influenced by the Indian monsoon. In mid-latitudes of inland Asia (Pamir-Alay and Tien Shan), there is no evidence of glacier advances during mid-MIS 3; these areas are presently nourished by precipitation from westerly systems.

\section{CONCLUSIONS}

Four glacier advance stages since the last glacial were defined for the north face of the Turkestan range, based on the geographical position and elevation, morphology and ecological characteristics of moraines. During Turkestan Stage I, during the last glacial (likely during MIS 2), glaciers expanded to about 5-10 km downstream from the current glacier termini. Multiple buried soil layers of a lateral moraine in the frontal area of Asan-Usin glacier formed between about $>48$ and 42 kyr BP (mid-MIS 3). These thick buried soil layers are records of significant warm intervals during mid-MIS 3, and are evidence of a period of glacier stagnation or recession. During mid-MIS 3, the scale of glaciers in the study area was small compared to the glacier expansion of MIS 2 during the last glacial. There is a possibility that glacier variation in mid-MIS 3 in the study area differed from that of other mountain areas, influenced by the Indian monsoon. 


\section{ACKNOWLEDGEMENTS}

We thank S. Iwata, H. Fukusawa, H. Matsuyama, S. Tsukamoto and A. Kadono for helpful advice and comments, T. Nakamura for radiocarbon-dating measurements, and G. Glazirin, F. Pertziger, A. Ni and M. Petrov for helpful advice and information. We also thank L. Owen and reviewers for valuable comments on the manuscript. Many thanks are extended to the Korotkov family of Tashkent, Republic of Uzbekistan, and T. Kadomatsu for supporting fieldwork and providing accommodation, and Kyrgyz and Tajik nomads for support in the field.

\section{REFERENCES}

Aizen, V.B., E.M. Aizen and J.M. Melack. 1995. Climate, snow cover, glaciers and runoff in the Tien Shan, central Asia. Water Resour. Bull., 31(6), 1113-1129.

Bäumler, R., W. Zech, A. Ni and O. Savoskul. 1999. Soil geographical and pedogeochemical studies on Pleistocene and Holocene glaciation in the northwestern Tien Shan (Uzbekistan). Z. Gletscherkd. Glazialgeol., 35(2), 147-173.

Bennett, M.R. and N.F. Glasser. 1996. Glacial geology: ice sheets and landforms. Chichester, John Wiley \& Sons.

Bronk Ramsey, C. 2001. Development of the radiocarbon program OxCal. Radiocarbon, 43(2A), 355-363.

Burtman, V.S. and P. Molnar. 1993. Geological and geophysical evidence for deep subduction of continental crust beneath the Pamir. Geol. Soc. Am. Spec. Pap. 281.

Derbyshire, E., Y. Shi, J. Li, B. Zheng, S. Li and J. Wang. 1991. Quaternary glaciation of Tibet: the geological evidence. Quat. Sci. Rev., 10(6), 485-510.

Dyke, A.S. and V.K. Prest. 1987. Late Wisconsinan and Holocene history of the Laurentide ice sheet. Géogr. Phys. Quat., 41(2), 237-263.

Eyles, N., C.H. Eyles and A.D. Miall. 1983. Lithofacies types and vertical profile models: an alternative approach to the description and environmental interpretation of glacial diamict and diamictite sequences. Sedimentology, 30(3), 393-410.

Gellatly, A.F., F. Röthlisberger and M.A. Geyh. 1985. Holocene glacier variations in New Zealand (South Island). Z. Gletscherkd. Glazialgeol., 21(1-2), 265-273.

Gillespie, A. and P. Molnar. 1995. Asynchronous maximum advances of mountain and continental glaciers. Rev. Geophys., 33(3), 311-364.

Grosswald, M.G., M. Kuhle and J.L. Fastook. 1994. Würm glaciation of Lake Issyk-Kul area, Tian Shan Mts.: a case study in glacial history of central Asia. GeoJournal, 33(2-3), 273-310.

Heuberger, H. and V.V. Sgibnev. 1998. Paleoglaciological studies in the Ala-Archa National Park, Kyrgyzstan, northwestern TianShan mountains, and using multitextural analysis as a sedimentological tool for solving stratigraphical problems. Z. Gletscherkd. Glazialgeol., 34(2), 95-123.

Humlum, O. 1977. Genesis of layered lateral moraines: implications for palaeoclimatology and lichenometry. Geograf. Tid., 77, 65-72.

Kitagawa, H., T. Masuzawa, T. Nakamura and E. Matsumoto. 1993. A batch preparation method for graphite targets with low background for AMS ${ }^{14} \mathrm{C}$ measurements. Radiocarbon, 35(2), 295-300.

Lehmkuhl, F. 1998. Extent and spatial distribution of Pleistocene glaciations in eastern Tibet. Quat. Int., 45-46, 123-134.
Lyså, A. and I. Lønne. 2001. Moraine development at a small HighArctic valley glacier: Rieperbreen, Svalbard. J. Quat. Sci., 16(6), 519-529.

Meiners, S. 1997. Historical to post glacial glaciation and their differentiation from the Late Glacial period on examples of the Tian Shan and the N.W. Karakorum. Geolournal, 42(2-3), 259-302.

Nakamura, T. and 9 others. 2000. The HVEE Tandetron AMS system at Nagoya University. Nucl. Instrum. Meth. Phys. Res. B, 172(1), 52-57.

Narama, C. 2001. Glacier variations in the Pamir-Alai and West Tien Shan mountains, central Asia over the last ninety years. Geogr. Rep. Tokyo Metropol. Univ. 36, 37-48.

Narama, C. 2002. Late Holocene variation of the Raigorodskogo Glacier and climate change in the Pamir-Alai, central Asia. Catena, 48(1-2), 21-37.

Owen, L.A., U. Kamp, J.Q. Spencer and K. Haserodt. 2002a. Timing and style of late Quaternary glaciation in the eastern Hindu Kush, Chitral, northern Pakistan: a review and revision of the glacial chronology based on new optically stimulated luminescence dating. Quat. Int., 97-98, 41-55.

Owen, L.A., R.C. Finkel, M.W. Caffee and L. Gualtieri. 2002 b. Timing of multiple late Quaternary glaciations in the Hunza Valley, Karakoram Mountains, northern Pakistan: defined by cosmogenic radionuclide dating of moraines. Geol Soc. Am. Bull., 114(5), 593-604.

Pertziger, F.I. 1996. [Abramov glacier data reference book: climate, runoff, mass balance]. Münich, Technical University. [In Russian.]

Petrov, N.B. and A.S. Schetinnikov. 1974. Katalog lednikov SSSR [Inventory of glaciers of the USSR]. Leningrad, Gidrometeoizdat.

Phillips, W.M., V.F. Sloan, J.F. Shroder, P. Sharma, M. Clarke and H.M. Rendell. 2000. Asynchronous glaciation at Nanga Parbat, northwestern Himalaya Mountains, Pakistan. Geology, 28(5), 431-434.

Richards, B.W., L.A. Owen and E.J. Rhodes. 2000. Timing of Late Quaternary glaciations in the Himalayas of northern Pakistan. J. Quat. Sci., 15(3), 283-297.

Rost, K.T. 2000. Pleistocene paleoenvironmental changes in the high mountain ranges of central China and adjacent regions. Quat. Int., 65-66, 147-160.

Röthlisberger, F. and M.A. Geyh. 1985. Glacier variations in Himalayas and Karakorum. Z. Gletscherkd. Glazialgeol., 21(1-2), 237-249.

Savoskul, O.S. and O.N. Solomina. 1996. Late-Holocene glacier variations in the frontal and inner ranges of Tian Shan, central Asia. Holocene, 6(1), 25-35.

Small, R.J. 1983. Lateral moraines of Glacier de Tsidjiore Nouve: form, development, and implications. J. Glaciol., 29(102), 250-259.

Velichko, A.A. and I.M. Lebedeva. 1974. An attempted palaeoglaciological reconstruction for the Western Pamirs. Mater. Glyatsiol. Issled. 23, 109-117.

Yasunari, T. and Y. Fujii. 1983. Climate and glaciers of the Himalayas. Tokyo, Tokyo-do Shuppan. [In Japanese.]

Zech, R., U. Abramowski, B. Glaser, P. Sosin, P.W. Kubik and W. Zech. 2005. Late Quaternary glacial and climate history of the Pamir Mountains derived from cosmogenic ${ }^{10} \mathrm{Be}$ exposure ages. Quat. Res., 64(2), 212-220.

Zech, W., B. Glaser, A.A. Ni, M. Petrov and I. Lemzin. 2000. Soils as indicators of the Pleistocene and Holocene landscape evolution in the Alay range (Kyrgystan). Quat. Int., 65-66, 161-169. 